\title{
Nerve inflammation halts trial for Alzheimer's drug
}

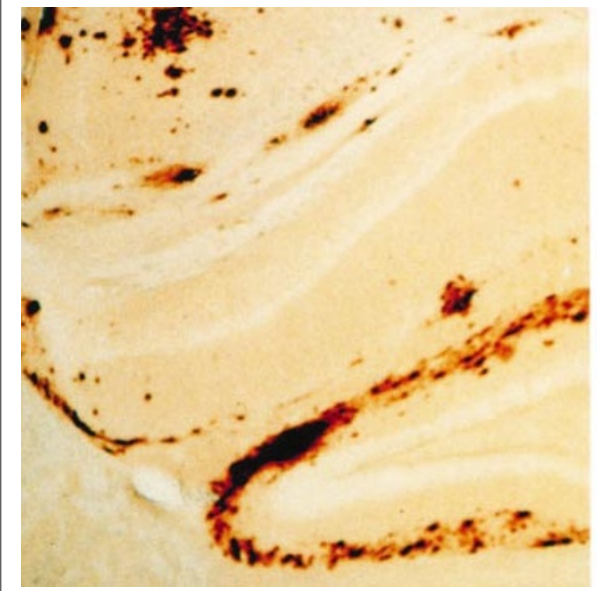

Before and after: plaques of amyloid- $\beta$ (left) in mouse brain can be treated with the drug AN-1792.

\section{Erika Check, Washington}

Trials of a new immunotherapy drug for Alzheimer's disease have hit a roadblock, with four of the participants developing potentially serious problems in the nervous system. Some researchers say the side-effect could have been anticipated before the trial began.

The drug's manufacturer, Elan of Dublin in Ireland, and its collaborating company, Wyeth-Ayerst of Madison, New Jersey, announced on 18 January that they were temporarily suspending a 360-patient trial of the drug, AN-1792, being carried out in the United States and Europe, while they investigate the problem. The four patients, all based in France, show "clinical signs consistent with inflammation in the central nervous system", the statement says.

Max Gershenoff, a spokesman for Elan, declined to elaborate on what led the investigators to diagnose the inflammation. He says the company hopes that the safety-monitoring committee that has been asked to establish the source of the inflammation will do so before the patients receive their next scheduled dose of the drug. A Wyeth-Ayerst spokesman says that one of the patients has already recovered.

Three years ago, Elan reported that AN1792 attacks tangles of human amyloid- $\beta$ protein, called plaques, in the brains of transgenic mice (see D. Schenk et al. Nature 400, 173-177; 1999). These plaques are diagnostic of Alzheimer's disease. Elan began phase I trials (for human safety) in December 1999 and reported no ill effects in 80 recipients of the drug. Last October, the company began its phase IIA trial to evaluate the drug's effectiveness against the symptoms of Alzheimer's.

But some scientists warn that AN-1792 could cause a dangerous autoimmune response in humans. The drug contains a synthetic version of amyloid- $\beta$, and causes the body's immune system to attack amyloid$\beta$ plaques. But scientist say the autoimmune response might also target amyloid precursor protein, which gives rise to amyloid- $\beta$. If it does, the side-effects could be devastating, because the precursor protein is found in many normal cells, including neurons.

"Some people have predicted that inflammation would be a side-effect," says Stephen Robinson, a neuroscientist at Monash University in Victoria, Australia.

Robinson says he is concerned that Elan has not reported a crucial safety test of its vaccine. The company tested the vaccine in transgenic mice that had brain plaques made of human amyloid- $\beta$ proteins. But mice have their own form of amyloid- $\beta$ and amyloid precursor protein. Elan has not published information on whether innoculating mice with mouse amyloid- $\beta$ causes them to mount an immune response against their own amyloid precursor protein, says Robinson.

"What you're doing in the transgenic mice is simply clearing human amyloid from their brains and leaving the mouse amyloid intact," Robinson says. "The key experiment would be to take wild-type mice and innoculate them against their own mouse amyloid$\beta$ and amyloid precursor protein.”

Gershenoff would not comment on whether those tests had been carried out. "We haven't made any announcement about that," he says.

Researchers say that, as Elan has already tested AN-1792 in 360 patients in clinical trials in the United States and Europe, it may be reluctant to blame the drug for the inflammation in the French patients. "It's premature to be overly concerned about this, given the small number of patients involved," says Karen Duff, an associate professor of psychiatry at New York University.

\section{Progress in human genetics hindered by reluctance to share}

\section{David Adam}

Data sharing in human-genetics research is being hampered by concerns over intellectual property rights, says one of the first studies to try to quantify the problem.

Of the 1,240 human geneticists surveyed by a team led by Eric Campbell of the Institute for Health Policy at Massachusetts General Hospital, Boston, almost half complained that a co-worker had refused them access to data, information or materials in the past three years.

According to $28 \%$ of the survey respondents, such refusals meant that they could not replicate published work, and $58 \%$ felt that their own research had suffered as a result. The survey's findings were published on 23 January in the Journal of the American Medical Association (287, 473-480; 2002).

Requests for materials, such as cell lines or the 'knockout' mice used to help to identify gene function, were refused more often $(35 \%)$ than requests for extra data $(25 \%)$ or methods $(16 \%)$.

"It may be that material-transfer agreements have become so complex and demanding that they inhibit sharing," says Campbell. Universities often require researchers to complete copious paperwork to ensure that the institution retains the intellectual property rights to any work deriving from the materials before they are handed over.

Joann Boughman, executive vicepresident of the American Society of Human Genetics, agrees. "Transfer agreements are now horrendously complicated," she says. "They used to be simple exchanges between scientists, but they have now evolved into complex business arrangements."

Four-fifths of those who admitted to not honouring a request cited the time and effort needed to locate or produce materials as a reason.

"The difficulty is time," agrees Kay Davies, a human-genetics researcher at the University of Oxford. "In the early days of our work we were getting three or four requests a day for probes and producing them is almost a full-time job."

Despite the scale of the problem, researchers contacted by Nature denied that there is a culture of secrecy in human genetics. "If anything is delaying progress in the field, it is changing attitudes towards intellectual property, rather than a reluctance to share," says Robert Ferrell, chair of human genetics at the University of Pittsburgh in Pennsylvania. 